\title{
OVATKO YLIOPISTOT SYRJINNÄSTÄ VAPAITA TILOJA?
}

Pääkirjoitus

Pohjoismaat ovat edelläkävijöitä tasa-arvossa, mutta siitä huolimatta monet lapset, nuoret, aikuiset ja iäkkäät joutuvat kokemaan syrjintää. Se voi johtua sukupuolesta, seksuaalisesta suuntautumisesta, etnisyydestä, sairaudesta, vammaisuudesta, sosiaalisesta luokasta tai jopa siitä, ettei ole "hyvä tyyppi". Syrjintä ei missään muodossa kuulu yhteiskuntaamme eikä se ikinä ole mielipidekysymys. Syrjintää ei voi perustella omalla vakaumuksella, mielipiteen oikeudella tai sananvapaudella.

Tasa-arvo ja syrjimättömyys ovat perusarvoja.Yliopistoissa ei sallita syrjintää tai kiusaamista (Yhdenvertaisuuslaki 1325/2014). Lain lisäksi yliopistollisen toiminnan eli opettamisen, tutkimisen, opiskelun ja vaikuttamisen jatkuva arviointi on välttämätöntä,jotta yhteisön jäsenille turvataan opiskelu- ja työrauha, toimintaympäristön esteettömyys, viihtyisyys, turvallisuus sekä yksilöiden tasapuolinen kohtelu. Syrjimättömyyden vaade edellyttää, että jokainen hyväksytään tasa-arvoisena yhteisön jäsenenä. Syrjinnän kohteena oleminen ei ole pelkästään henkilökohtaista. Jos syrjintää ilmenee, on se koko yhteisön ongelma, johon kaikilla yhteisön jäsenillä on velvollisuus puuttua.

Yliopistolla on organisaationa vastuu syrjintään puuttumisessa. Kaikilla yliopistoyhteisön jäsenillä, niin opiskelijoilla kuin työntekijöillä, on vastuu osoittaa teoillaan ja puheillaan, etteivät he hyväksy syrjintä. Tällöin syrjimättömyyden normista poikkeavat joutuvat ahtaalle. Tasa-arvon ja yhdenvertaisuuden tulee näkyä myös työyhteisön arvoissa ja johtamisessa.

Tasa-arvolaki ja yhdenvertaisuuslaki uudistuivat vuonna 2015. Yhdenvertaisuus ei ole pelkästään syrjimättömyyttä vaan kyse on ymmärtämisestä, ajattelutavasta, asenteista ja toisten huomioon ottamisesta.

Henkilöstön tasa-arvoinen ja yhdenvertainen kohtelu edellyttävät, että yliopistoyhteisössä noudatetaan yhdenvertaista ja tasa-arvoista henkilöstö- ja palkkapolitiikkaa. Riippumatta sukupuolesta, tieteenalasta, asemasta, henkilöstöryhmästä, palvelussuhteen laadusta tai iästä, henkilöillä tulee olla tasa-arvoiset mahdollisuudet edetä urallaan ja kehittää omaa osaamistaan. Rekrytoinnit, uralla eteneminen ja palkkaus ovat joko syrjimättömyyden tai syrjinnän paikkoja. (Esim. Laki naisten ja miesten tasa-arvosta 609/1986.) Kilpailu julkaisuista, tutkimusrahoituksista ja asemista saattaa kääntyä epätasa-arvoksi yksilöiden, yliopistojen ja eri tieteenalojen kesken. Jos puolustaa "omaa", voi tulla syrjineeksi jota kuta toista "hyvän" kilpailun ja puoliaan pitämisen nimissä. Niin välitön, välillinen kuin tahatonkin syrjintä on kuitenkin kiellettyä, ja tällaisen tunnistamisessa ja poistamisessa olisi paljon työtä ja oppimista niin yksilöille kuin instituutioille. 
Yliopistossa opiskelijavalinnan perusteiden ja opintosuoritusten arviointien tulisi olla mahdollisimman avointa.Yliopistossa opiskelevat ovat elämäntilanteiltaan ja iältään heterogeeninen ryhmä. Perheen, työn ja eri paikkakuntien välillä matkustaminen vaatii opiskelijoilta motivaatiota ja rahaa sekä yliopistoilta erilaisten pedagogisten ratkaisujen toteuttamista opetuksen laadun kärsimättä. Kuinka opetuksen voisi toteuttaa siten, etteivät pedagogiset ratkaisut syrjisi opiskelijoita, ja missä määrin opiskelijoiden toiveita on aidosti mahdollista toteuttaa, jottei vastaavasti toisia opiskelijoita syrjisi? Opiskelijat eivät saa tulla suhteissa toisiinsa epätasa-arvoiseen asemaan.

Yliopisto on paikka, jossa opiskellaan muun ohella niin sanottuja työelämätaitoja. Syrjimättömyyden ja tasa-arvon käytännöt ovat olennainen osa näitä taitoja.Yksi keino tehdä syrjimättömyydestä eksplisiittistä ja nostaa esiin muun muassa keinoja puuttua syrjiviin tilanteisiin, on julistaa yliopisto, tiedekunta tai laitos syrjinnästä vapaaksi tilaksi (ks. https://yhdenvertaisuus.fi/syrjinnastavapaa.fi). Tällöin esimerkiksi seminaarien tai luentojen aluksi voidaan yhdessä käydä läpi, mitä syrjimättömyys tarkoittaa ja millainen toiminta ei siihen kuulu.

Tässä JANUKSEN numerossa on neljä artikkelia. Jenni-Mari Räsänen analysoi artikkelissaan toimintakyvyn arviointimenetelmien käyttöön liittyviä jännitteitä kotiin vietävissä palveluissa. Arviointimenetelmien käyttö vaatii työntekijöiltä herkkyyttä siitä, mitä käsitteitä käytetään, milloin arviointi tehdään ja miten se perustellaan. Artikkeli tuo arvokkaan ja kriittisen kontribuution laajemminkin mittareiden hyödyntämiseen työvälineenä. Pekka Pennanen ja Jyri Liukko tutkivat sosiaalipolitiikan järjestämistä muuttuvassa hyvinvointivaltiossa ja tarkastelevat tulosperustaista rahoitussopimusta julkisella sektorilla. Artikkelin mukaan mallin soveltamista perustellaan heikolla taloustilanteella, mallin mahdollistamilla paremmilla palveluilla ja eri sektorien välisellä yhteistyöllä.Tulokset kiinnittyvät erittäin kiinnostavasti ajankohtaiseen yhteiskunnalliseen keskusteluun. Sanna-Riitta Junnonen, Juha Hämäläinen, Pertti Tottö, Raija Väisänen, Otso Rantonen ja Paula Salo analysoivat sosiaalityöntekijöiden työn kuormittavuutta ja siinä tapahtuneita muutoksia vuosina 2000-2012. Artikkelissa keskitytään työn hallintaan, palkitsevuuteen ja työn tuottamiin paineisiin. Puhutteleva tutkimustulos on, että sosiaalityöntekijät kokivat enemmän kuormitusta työssään kuin psykologit, erityisopettajat tai lastentarhanopettajat. Sisko Piippo, Leo Nyqvist ja Mari Suonio analysoivat sosiaalityön opiskelijoiden reflektoimaa lähisuhdeväkivallasta oppimista. Oppiminen paikantui neljään kehykseen: toimintavalmiuksiin, kokemukselliseen reflektioon, ilmiöön liittyvään rajaamiseen ja asennemuutokseen. Lähisuhdeväkivallan tunnistaminen ja puheeksi ottaminen ovat olennaisen tärkeitä taitoja, joita tulee harjoitella sosiaalityössä jo opiskeluaikana.

Aini Pehkonen ja Eeva Jokinen

\section{KIRJALLISUUS}

Yhdenvertaisuuslaki 1325/2014. https://www.finlex.fi/fi/laki/alkup/2014/20141325 Luettu 25.4.2019. 